\title{
POTENSI BIRDWATCHING SEBAGAI SALAH SATU DAYA TARIK WISATA DI DESA WISATA JATIMULYO, KECAMATAN GIRIMULYO,KABUPATEN KULON PROGO
}

\author{
Fuadi Afif \\ NIDN 0515088702 \\ Email: fuadiafif@gmail.com \\ Sekolah Tinggi Pariwisata AMPTA Yogyakarta \\ Revi Agustin Aisyianita \\ NIDN 0509089001 \\ Email: aisyianita@gmail.com \\ Universitas Negeri Jakarta \\ Saptin Dwi Setyo Hastuti \\ NIDN 0527048702 \\ Email: saptin27@gmail.com \\ Sekolah Tinggi Pariwisata AMPTA Yogyakarta
}

\begin{abstract}
This study aims to identify the response of tourists in Jatimulyo Tourism Village towards the plan of developing birdwatching tourism. Birds have a strong attractiveness for certain groups of people, such as bird hobbies due to their diverse characteristics which have a high selling value. Jatimulyo Tourism Village is one of the tourism villages known for its bird diversity. Regarding that situation, the Jatimulyo government issued a Village Regulation (so-called Peraturan Desa or PerDes) about prohibition of hunting activities. It was already applied by sanctioning wild-life hunters, including bird hunter. However, the application of PerDes was not strong enough to protect the bird diversity. Thus, there must be alternatives program by utilizing the bird diversity to give economic advantages for the people. Birdwatching tourism is one of the alternatives and there is possibility to develop it in this village, considering this village has already been recognized as tourism village. This research was a quantitative research and employing survey with questionnaire as the instrument. There were 100 questionnaires given to the tourists in Jatimulyo Tourism Village to gather valid data. The term of birdwatching is still a foreign term for the people. The observation results show that most of the tourists had ever heard the term but did not know its meaning. However, most of the tourists were agreed with the alternative of developing this tourism village with birdwatching as one of the attractions but in one condition i.e. the tour package was not more than one day with affordable budget. They also wanted bird observation and photography as the activities of birdwatching. Furthermore, they needed professional guide to guide them along the tour.
\end{abstract}

Keywords : birdwatching, avitourism, tourism, tourism village

\section{PENDAHULUAN}

Tidak dapat dipungkiri salah satu latar belakang yang mendorong terjadinya perburuan dan penangkapan burung di habitat asalnya adalah karena faktor ekonomi. Burung yang hidup bebas di alam dipikat oleh pemikat burung, ditawarkan ke pengepul untuk disalurkan kepada para penghobi dan penghobi memelihara hingga burung tersebut bisa berkicau sehingga bisa dijual dengan harga yang tinggi.

Dalam proses yang dimulai dari pemikat sampai penghobi tidak sedikit burung yang mati akibat stress, sakit, dan mengalami cidera pada saat proses pengiriman. Melalui pendekatan avitourism khususnya birdwatching membuat keberadaan burung akan memberikan keuntungan nonmateri dan materi untuk masyarakat sekitar tanpa harus 
menangkap secara membabibuta agar dapur tetap mengeluarkan asap. Seperti halnya marine tourism yang menawarkan aktivitas melihat dan menyelam bersama ikan pari, ikan hiu dan ikan paus di objek wisata laut yang terkenal. Aktivitas - aktivitas wisata tersebut terbukti mampu mengurangi kegiatan masyarakat untuk memburu ikan yang mempunyai nilai untuk kegiatan pariwisata. Irianto B (1998) menilai bahwa nilai ekonomis kegiatan wisata di Banda dan di Pantai Sorbat Indah lebih tinggi dari nilai ekonomis kegiatan perikanannya. Hal tersebut disebabkan karena kegiatan perikanan tangkap bersifat skala kecil dan wilayah operasinya hanya di daerah pesisir.Kedatangan Hiu Paus yang menjadi obyek wisata, menjadikan magnet bagi turis lokal dan mancanegara, pejabat dan masyarakat biasapun berbondong-bondong ingin menyaksikan langsung daridekat ikan raksasa yang jinak ini. Balai Besar Taman Nasional Teluk mencatat sudah terdapat sebanyak 5.722 pengunjung di Teluk Cendrawasih, Provinsi Papua Baratpada tahun 2015, dengan Penerimaan Negara Bukan Pajak (PNBP) Rp.586.160.000 (Sumber : Balai Besar Taman Nasional Teluk Cendrawasih, 2016).

Dengan melihat pengaruh pariwisata dalam upaya pelestarian keanekaragaman fauna dan kesejahteraan penduduk sekitar, maka diharapkan kegiatan birdwatchingdapat menjadi salah satu upaya yang memiliki peranan dalam pelestarian keanekaragaman burung khususnya di Jatimulyo.

Desa Wisata Jatimulyo terletak di perbukitan Menoreh yang merupakan daerah dataran tinggi dan masih dipenuhi oleh vegetasi. Hal ini menjadi salah satu penyebab tingginya keanekaragaman burung di kawasan ini. Vegetasi tidak hanya berfungsi sebagai habitat bagi para burung namun juga sebagai sumber pakan bagi para burung. Keanekaragaman satwa liar yang terdapat di suatu kawasan mampu dijadikan sebagai indikator untuk menilai kualitas lingkungan. Mac Kinnon (2010) menyebutkan bahwa burung merupakan indikator yang baik untuk mengidentifikasi keragaman hayati di sebuah kawasan dan juga dapat menjadi indikator untuk menilai perubahan lingkungan yang terjadi.

\section{LITERATURE REVIEW}

Kabupaten Kulon Progo tercatat memiliki sekitar 227 jenis burung dari 508 jenis burung yang ada di Pulau Jawa. Artinya, 47\% jenis burung di Pulau Jawa terdapat di Kabupaten Kulon Progo. Desa Wisata Jatimulyo memiliki keunikan potensi berupa keanekaragaman burung yang tinggi sehingga mampu menarik minat wisatawan mancanegara untuk melakukan aktivitas birdwatching.Penelitian yang telah dilakukan oleh Brata dan Sara (2016) menyebutkan bahwa Dukuh Banyunganti, diketahui bahwa terdapat 28 jenis burung yang termasuk dalam 17 famili di Desa Wisata Jatimulyo, Selain memiliki keanekaragaman jenis Capung yang tinggi, Jatimulyo juga kaya akan keanekaragaman burung. Menurut Sulfiantono seperti yang diliput oleh KR Jogja terdapat 94 jenis burung di kawasan ini (24\% total jenis burung di DIY).Menyadari bahwa lingkungannya menyimpan kekakayaan sumberdaya alam berupa keragaman burung, perangkat desa Jatimulyo mengeluarkan Peraturan Desa (Perdes) yang melarang kegiatan perburuan dan sudah menerapkan sanksi bagi pemburu satwa liar, termasuk pemburu burung.

Penguatan daya tarik birdwatching sebagai salah satu atraksi wisata di Desa Wisata Jatimulyo perlu dilakukan untuk memaksimalkan potensi yang ada dan memberikan alternatif daya tarik wisata baru bagi wisatawan. Berdasarkan hasil studi Penyusunan Analisis Daya Saing Produk Wisata Ecotourism yang disusun oleh Dinas Pariwisata Provinsi D.I.Yogyakarta pada tahun 2015, identifikasi potensi birdwatching di D.I.Yogyakarta masih terpusat pada satu kluster saja, yaitu Kluster Merapi. Belum teridentifikasinya potensi wisata birdwatching di Kulon Progo menjadikan program-program ekowisata terkait birdwatching masih minim. Potensi wisata birdwatching menjadi peluang yang menjanjikan bagi industri pariwisata. 
Segmentasi wisatawan dan aktivitas birdwatching yang berbeda dengan wisata pada umumnya, dapat mendorong peningkatan jumlah dan lama tinggal wisatawan di Desa Wisata Jatimulyo. "Penguin Parade" di Philip Island, Melbourne, terbukti mampu menarik kunjungan wisatawan sebanyak 607.888 orang pada tahun 2015 (State of Victoria Philip Island Nature Parks, 2015). Sebuah studi yang dilakukan di salah satu desa di Polandia menyebutkan bahwa wisatawan rela membelanjakan sebanyak \pm US $\$ 60$ per orang per kunjungan untuk melihat Bangau (UNDP, 2015) dan wisatawan di United Kingdom membelanjakan sebesar $\pm £ 55,96$ per orang per kunjungan untuk melihat burung (Molloy, 2011). Biro perjalanan wisata di USA bernama WINGS menawarkan paket wisata birdwatching dengan durasi sekitar $6-23$ hari. Salah satu paket wisata yang ditawarkan oleh WINGS adalah birdwatching di Maluku, Indonesia dengan durasi wisata selama 22 hari dengan harga US \$ 10.500 per orang. Kegiatan wisata birdwatching yang dilakukan di USA pada umumnya terbagi menjadi tiga jenis kegiatan, yaitu: untuk keperluan konservasi/ penelitian, fotografi, dan memberi makan/ feeding (U.S. Fish and Wildlife Service, 2016).

Tingginya permintaan pasar wisatawan mancanegara terhadap birdwatching yang didukung dengan tingginya potensi keanekaragaman burung di Kulon Progo, khususnya Desa Jatimulyo menjadikan penelitian berjudul "Potensi Birdwatching Sebagai Salah Satu Daya Tarik Wisata Di Desa Wisata Jatimulyo, Kecamatan Girimulyo, Kabupaten Kulon Progo" perlu dilakukan. Tujuan dari penelitian ini adalah untuk mengidentifikasi respon wisatawan di Desa Wisata Jatimulyo terhadap rencana pengembangan wisata birdwatching. Penelitian ini diharapkan mampu menjadi pilot project pengembangan birdwatching sebagai daya tarik wisata di D.I.Yogyakarta dan di seluruh Indonesia.

\section{METODE PENELITIAN \\ Lokasi Penelitian}

Penelitian ini dilakukan di Desa Wisata Jatimulyo, Kecamatan Girimulyo, Kabupaten Kulon Progo. Pemilihan Desa Wisata Jatimulyo sebagai lokasi penelitian memiliki beberapa pertimbangan, antara lain:

a. Merupakan desa wisata yang masih tergolong baru (diresmikan tahun 2015) namun sudah ramai dikunjungi oleh wisatawan, baik nusantara maupun domestik (memiliki jumlah kunjungan wisatawan tertinggi ketiga di Kulon Progo).

b. Salah satu daya tarik wisata di Desa Wisata Jatimulyo untuk kegiatan birdwatching, yaitu tingkat keanekaragaman burung yang tinggi dengan luas wilayah yang tidak terlalu luas sehingga memperbesar kemungkinan untuk dapat bertemu dengan burung.

\section{Pendekatan Penelitian}

Penelitian ini menggunakan pendekatan kuantitatif. Pendekatan kuantitatif merupakan pendekatan penelitian yang berlandaskan pada filsafat positivisme yang digunakan untuk meneliti pada populasi atau sampel tertentu. Pengumpulan data dilakukan menggunakan instrumen penelitian dan analisis data bersifat kuantitatif/ statistik (Sugiyono, 2013). Instrumen penelitian yang digunakan pada penelitian ini adalah kuesioner.

\section{Teknik Pengumpulan Data}

Pengumpulan data dilakukan dengan menggunakan kuesioner sebagai alat bantu penelitian. Penentuan populasi dan sampel responden didapat dengan melihat data kunjungan wisatawan Desa Wisata Jatimulyo. Data dari Buku Statistik Kepariwisataan DIY menyebutkan bahwa jumlah kunjungan wisatawan Desa Wisata Jatimulyo pada tahun 2016 adalah 118.626 orang. Jumlah tersebut terbagi menjadi 116.986 wisatawan nusantara dan 1.640 wisatawan mancanegara.

Pengambilan sampel dilakukan dengan menggunakan teknik simple random sampling dengan menggunakan pendekatan rumus Slovin. Teknik simple random sampling merupakan teknik pengambilan 
sampel yang dilakukan secara acak tanpa memperhatikan strata yang ada dalam populasi karena populasi dianggap homogen (Sugiyono, 2013).

Berdasarkan hasil perhitungan sesuai dengan rumus Slovin tersebut, diperoleh jumlah sampel untuk penelitian ini adalah sebanyak 100 responden. Pada penelitian ini telah disebarkan kuesioner kepada 106 wisatawan di Desa Wisata Jatimulyo untuk memperoleh data yang dibutuhkan. Pembagian kuesioner dilakukan secara tersebar di beberapa daya tarik wisata yang ada di Desa Wisata Jatimulyo.

\section{HASIL PENELITIAN PEMBAHASAN}

Pengumpulan data di lapangan menghasilkan informasi mengenai respon wisatawan di Desa Wisata Jatimulyo terhadap rencana pengembangan wisata birdwatching. Respon dari wisatawan memiliki peranan penting karena wisatawan eksisting di Desa Wisata Jatimulyo merupakan segmentasi pasar utama wisata birdwatching. Hasil penelitian yang diperoleh dari wisatawan yang berkunjung ke Jatimulyo meliputi pengetahuan wisatawantentang birdwatching, respon wisatawan terhadap rencana pengembangan wisata birdwatching, kegiatan birdwatching yang diinginkan wisatawan, durasi wisata birdwatching, biaya yang dikeluarkan wisatawan dan harapan fasilitas birdwatching.

\section{Karakteristik Responden}

Dari hasil penelitian, dapat diambil kesimpulan bahwa wisatawan Desa Wisata Jatimulyo tidak didominasi oleh salah satu gender saja, hal ini terlihat dari perbedaan persentase antara laki-laki (57\%) dan perempuan $(43 \%)$ tidak terlalu signifikan, sehingga dapat ditarik kesimpulan bahwa Desa Wisata Jatimulyo diminati oleh wisatawan laki-laki maupun perempuan. Kemudian Desa Wisata Jatimulyo menjadi objek wisata yang diminati oleh anak muda, hal ini didapatkan dari hasil data yang menunjukkan bahwa Wisatawan Desa Wisata Jatimulyo didominasi oleh wisatawan muda, yang berusia $20-25$ tahun (58\%) dan dibawah 20 tahun (26\%).

Selanjutnya wisatawan Desa Wisata Jatmulyo memiliki latar belakang profesi yang cukup beragam, seperti: aktivis, buruh, guru, karyawan, mahasiswa, pelajar, peneliti, perawat, PNS, wiraswasta, dan sebagian kecil wisatawan tidak bekerja. Sesuai dengan data yang didapat untuk latar belakang profesi, SMA/SMK (65\%) dan S1 (17\%) yang berprofesi sebagai mahasiswa (55\%) dan karyawan (16\%). Hal ini menunjukkan bahwa Desa Wisata Jatimulyo yang menawarkan kekayaan alam sebagai daya tarik utama mampu menarik minat wisatawan dari berbagai latar belakang profesi.

\section{Persepsi Wisatawan Desa Wisata} Jatimulyo Terhadap Birdwatching

Birdwatching merupakan istilah yang baru bagi masyarakat umum, oleh karena itu dalam studi ini peneliti terlebih dahulu mencari tahu mengenai persepsi wisatawan terhadap birdwatching. Berdasarkan hasil survei yang dilakukan pada 106 responden yang ditampilkan pada gambar1, hanya $22 \%$ responden yang tahu birdwatching, seperti hasil yang terdapat pada gambar1, sebagian besar responden (47\%) menyatakan bahwa mereka pernah mendengar istilah tersebut namun belum memahami maknanya. Sebanyak 31\% responden menyatakan bahwa mereka tidak tahu sama sekali tentang birdwatching.

Meskipun hanya sebagian kecil wisatawan yang memahami konsep wisata birdwatching, namun terlihat pada gambar2 sebagian besar wisatawan (96\%) menyatakan bahwa mereka setuju terhadap rencana pengembangan wisata birdwatching di Desa Wisata Jatimulyo.Pengembangan wisata birdwatching diharapkan mampu memberikan alternatif kegiatan wisata yang baru sehingga tidak monoton dan membosankan.Selain itu, wisata birdwatching juga diharapkan mampu memberikan nilai tambah dan pengalaman baru bagi wisatawan, sehingga wisatawan yang datang tidak hanya bersenang - senang dan rekreasi namun juga mendapatkan nilai edukasi. 
3. Kegiatan Wisata yang Diinginkan oleh Wisatawan Desa Wisata Jatimulyo Terhadap Birdwatching

Pengamatan burung atau birdwatching pada umumnya terdiri dari dua jenis kegiatan, yaitu kegiatan pengamatan burung kemudian mengidentifikasi jenis spesies berdasarkan karakteristik yang dijumpai, dan kegiatan fotografi untuk keperluan dokumentasi. Pada gambar3 sebagian besar responden $(59 \%)$ menginginkan kegiatan fotografi dan pengamatan burung dapat dilakukan di Desa Wisata Jatimulyo. Menanggapi keinginan wisatawan tersebut, maka perlu dibuat jalur trekking di Desa Wisata Jatimulyo yang mampu mengakomodasi kebutuhan wisatawan birdwatching untuk melakukan kegiatan pengamatan burung dan fotografi. Pembuatan jalur trekking diawali dengan kegiatan pemetaan terlebih dahulu. Tujuan dari kegiatan pemetaan adalah untuk menentukan titik - titik strategis untuk pengamatan dan fotografi.

Hasil survei di lapangan yang ditampilkan pada gambar4 menunjukkan bahwa sebagian besar wisatawan $(71 \%)$ menginginkan kegiatan wisata birdwatching dapat dilakukan dalam durasi waktu satu hari sedangkan sebanyak 29\% wisatawan menginginkan kegiatan wisata birdwatching bisa dilakukan lebih dari satu hari. Pengembangan fasilitas akomodasi seperti homestay atau guest house perlu dilakukan untuk memenuhi kebutuhan wisatawan birdwatching yang ingin menginap.

\section{Kesediaan Wisatawan Desa Wisata Jatimulyo Mengeluarkan Biaya}

Pada gambar5 ternyata sebagian besar wisatawan Desa Wisata Jatimulyo (77\%) menyatakan tidak keberatan untuk mengeluarkan biaya tambahan apabila mereka ingin menikmati paket wisata birdwatching, asalkan biaya tambahannya tidak lebih dari Rp 100.000,00. Hanya sebagian kecil wisatawan yang bersedia mengeluarkan biaya lebih dari Rp 100.000,00 untuk membeli paket wisata birdwatching. Sebagian beranggapan tidak perlu mengeluarkan biaya banyak untuk menikmati hal yang masih banyak tersedia bebas di alam. Hal ini cukup berbeda dengan biaya tour birdwatching di Slovakia yang paling murah (http://bird.watching.sk/price-list2014) untuk tour satu hari dengan harga 80 Euro atau 1.331.333 Rupiah dan tour setengah hari dengan harga 50 Euro atau 832.083 Rupiah.

\section{Fasilitas yang Diinginkan Wisatawan Desa Wisata Jatimulyo}

Kesediaan wisatawan untuk mengeluarkan biaya tambahan yang ditampilkan pada gambar6, harus diikuti dengan penyediaan fasilitas yang dapat digunakan wisatawan untuk melakukan kegiatan pengamatan burung. Hasil survei menunjukkan bahwa sebagian besar wisatawan (40\%) menginginkan adanya jasa pemandu professional yang dapat mendampingi wisatawan ketika melakukan kegiatan pengamatan burung. Sebanyak 26\% wisatawan mengharapkan ketersediaan buku panduan jenis burung, $14 \%$ wisatawan mengharapkan adanya persewaan homestay, $12 \%$ wisatawan mengharapkan adanya fasilitas persewaan binokuler dan monokuler untuk kegiatan pengamatan burung. Sebanyak 4\% wisatawan menginginkan adanya jasa pemandu, buku panduan, dan persewaan monokuler \& binokuler. Sedangkan 4\% lainnya menginginkan adanya jasa pemandu, homestay, pesewaan monokuler \& binokuler.

\section{KESIMPULAN}

Birdwatching merupakan istilah baru dan masih terdengar asing bagi masyarakat umum di Indonesia, termasuk bagi wisatawan di Desa Wisata Jatimulyo. Hanya sebagian kecil wisatawan (22\%) yang memahami istilah birdwatching, sebagian besar menyebutkan bahwa mereka sering mendengar istilah tersebut tapi belum memahami maknanya. Meskipun pengetahuan wisatawan terhadap birdwatchingmasih minim, namun sebagian besar wisatawan setuju jika di Desa Wisata Jatimulyo dikembangkan kegiatan wisata birdwatching sebagai alternatif daya tarik baru. Melihat fakta tersebut, maka langkah 
awal yang harus dilakukan oleh pihak pengelola adalah memperkuat nilai edukasi pada kegiatan wisata birdwatching. Pada tahap promosi, pihak pengelola perlu memperkuat upaya pengenalan produk (product knowledge) kepada calon wisatawan birdwatching. Perlu diingat bahwa wisatawan birdwatching tidak hanya berasal dari kelompok peneliti, pengamat burung, atau fotografi saja. Wisatawan umum yang saat ini sudah berkunjung di Desa Wisata Jatimulyo juga memiliki potensi menjadi wisatawan birdwatching (twitcher). Oleh karena itu, upaya pengenalan produk yang baik memiliki peranan penting dalam menarik minat wisatawan. Pada saat melakukan kegiatan wisata birdwatching juga perlu diberikan nilai - nilai edukasi. Twitcher harus memahami bahwa kegiatan birdwatching bukan hanya sekedar mengamati atau mengambil foto burung saja namun juga terdapat tujuan pelestarian di dalamnya.

Hasil observasi di lapangan menunjukkan bahwa sebagian besar wisatawan ingin melakukan kegiatan pengamatan burung dan fotografi. Pengelola Desa Wisata Jatimulyo perlu melakukan pemetaan yang dapat memberikan gambaran secara detail terkait titik - titik lokasi dimana burung - burung tersebut biasa terlihat, sehingga memudahkan para twitchers saat melakukan kegiatan pengamatan burung dan fotografi. Sebagian besar wisatawan di Desa Wisata Jatimulyo juga menginginkan paket wisata birdwatching dengan durasi wisata tidak lebih dari satu hari dan biaya yang bersedia dikeluarkan oleh wisatawan untuk membeli paket tersebut tidak lebih dari Rp 100.000,00. Pembuatan paket wisata birdwatching dengan durasi satu hari dengan biaya yang terjangkau dapat dikemas menjadi beberapa pilihan paket wisata, dengan memadukan antara jasa pemandu, persewaan peralatan birdwatching (seperti: buku panduan, monokuler, dan binokuler), dan penyediaan kebutuhan wisatawan seperti: snack, makan siang, homestay, dan lain - lain.

Pengemasan potensi keragaman jenis burung di Desa Wisata Jatimulyo menjadi sebuah paket wisata birdwatching tentu menjadi daya tarik baru bagi wisatawan karena dapat meningkatkan pengalaman berwisata. Pengembangan wisata birdwatching juga memiliki manfaat bagi pengelola, antara lain:

1. Daya tarik wisata baru mampu mendorong peningkatan jumlah wisatawan dan lama tinggal wisatawan sehingga berdampak juga pada peningkatan pendapatan masyarakat Desa Wisata Jatimulyo selaku pengelola desa wisata.

2. Wisata birdwatching tidak hanya memiliki dampak positif dari aspek finansial namun juga bagi kelestarian lingkungan sekitar. Jika keanekaragaman burung di Desa Wisata Jatimulyo menjadi daya tarik utama pariwisata, tentu kesadaran masyarakat untuk berkontribusi dalam menjaga kelestarian lingkungan tempat tinggal mereka yang juga merupakan habitat para burung juga akan meningkat.

Penelitian ini merupakan studi awal yang dilakukan untuk mengidentifikasi potensi pengembangan wisata birdwatching di Desa Wisata Jatimulyo, Kulon Progo. Hasil temuan pada penelitian ini memberikan gambaran mengenai respon wisatawan terhadap rencana pengembangan wisata birdwatching. Masih diperlukan penelitin lanjutan yang berkaitan dengan pemetaan titik - titik lokasi pengamatan burung, strategi pengelolaan wisata birdwatching, serta strategi promosi dan pemasaran wisata birdwatching yang bertanggungjawab.

\section{RFERENSI}

Irianto, Bambang, Muhamad Syukur, Noor Hasan, Sitti H. Talaohu. (1998). Valuasi Ekonomi Wisata Bahari Dan Perikanan Tangkap Di Maluku. Jurnal Agro Ekonomi, 17( 2), 38-58.

Brata, Wayan Bindo Ade \& Sara Puspareni P. (2016). Keanekaragaman Jenis Burung di Dukuh Banyunganti Desa Jatimulyo Kabupaten Kulon Progo. Yogyakarta: Universitas Atma Jaya Yogyakarta.

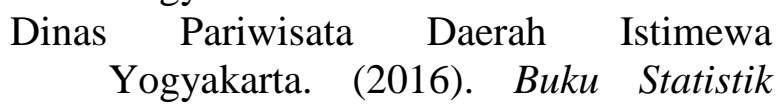


Kepariwisataan. Yogyakarta: Dinas Pariwisata Daerah Istimewa Yogyakarta.

Hiu Paus di Pantai Botubarani Gorontalo. (2017). Makasar: Balai Pengelolaan Sumberdaya Pesisir dan Laut Masakar. MacKinnon, J., K Phillips and B. van Balen. (2010). Burung-burung di Sumatera, Jawa, Bali dan Kalimantan.W., Rahardjaningtrah, A. Adikerana, P. Martodihardjo,E.K. Supardiyono, B van Balen (penerjemah); S., Sumadipura, A. Kartikasari (editor). Terjemahan dari: Fieldguide to the Birds of Borneo, Sumatera, Java, and Bali. Burung Indonesia, Bogor.
Sugiyono. (2013). Cara Mudah Menyusun Skripsi, Tesis, dan Disertasi. Bandung: Alfabeta.

Sulfiantono Arif. (2017). Konservasi Alam Konservasi Kita. Kedaulatan Rakyat.

United States Fish \& Wildlife Service. (2016). National Survey of Fishing, Hunting, and Wildlife - Associated Recreation. US: United States Fish \& Wildlife Service.

World Tourism Organization. (2014). Towards Measuring the Economic Value of Wildlife Watching Tourism in Africa - Briefing Paper. Madrid: UNWTO 


\section{Lampiran}

Gambar 1. Pengetahuan Wisatawan Mengenai Birdwatching

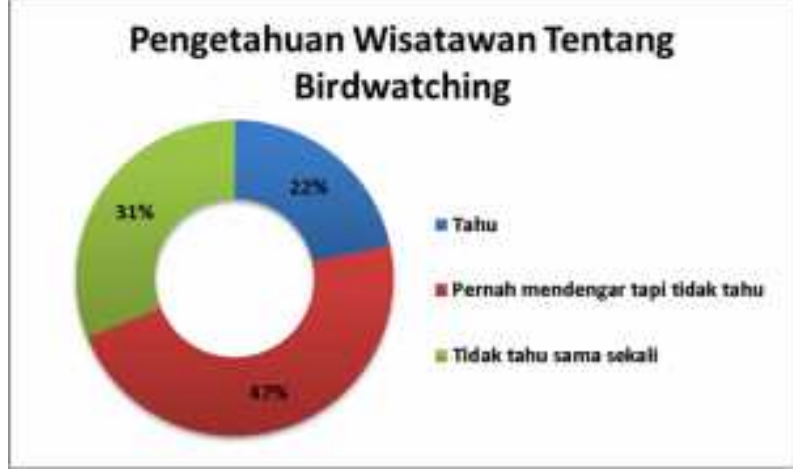

Gambar 2. Respon Wisatawan terhadap Rencana Pengembangan Wisata Birdwatching

Apakah Anda setuju jika dikembangkan wisata birdwatching di Jatimulyo?

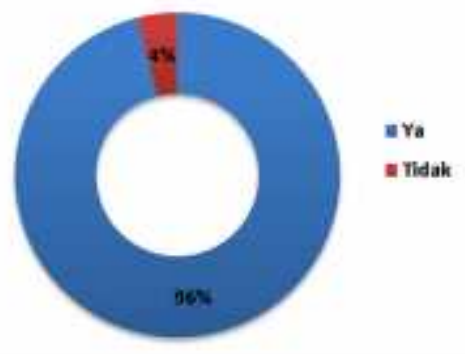

Gambar 3. Kegiatan Birdwatching yang Diinginkan Wisatawan

Kegiatan Birdwatching yang diinginkan Wisatawan Jatimulyo

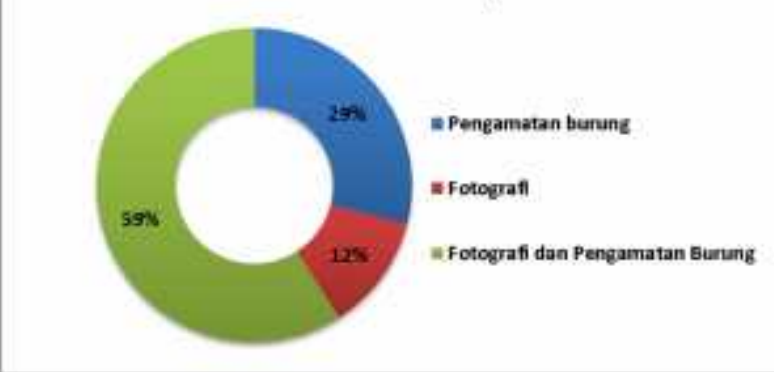

Gambar 4. Durasi Wisata Birdwatching yang Diharapkan Wisatawan Durasi Wisata Birdwatching yang Diharapkan Wisatawan

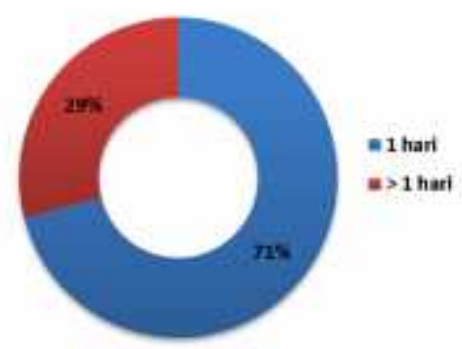


Gambar 5. Biaya Wisata Birdwatching yang Diinginkan Wisatawan

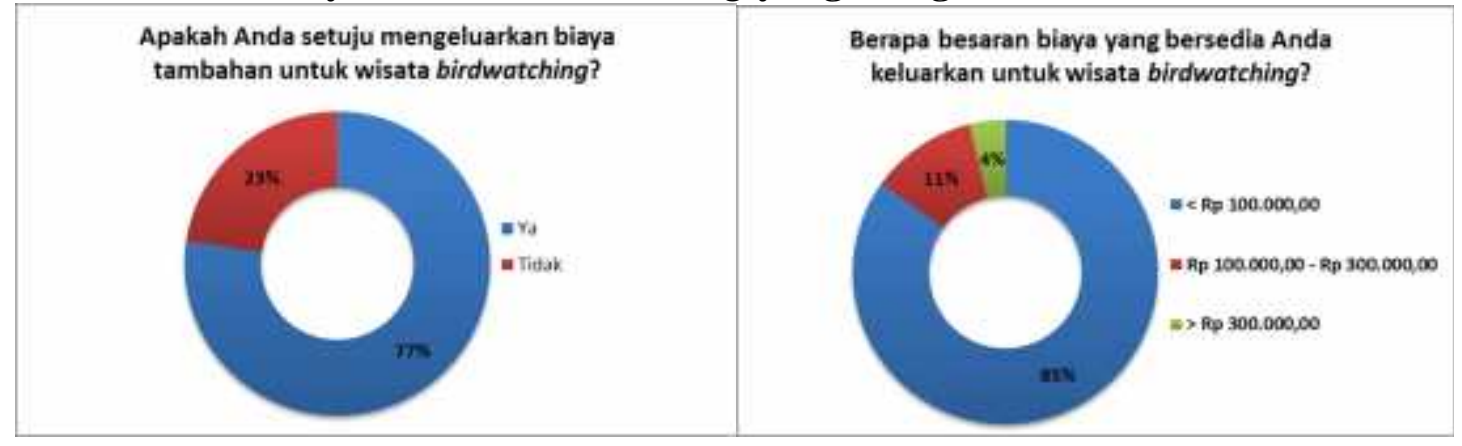

Gambar 6. Fasilitas Wisata Birdwatching yang Diharapkan Wisatawan Fasilitas Wisata Birdwatching yang Diharapkan Wisatawan Jatimulyo

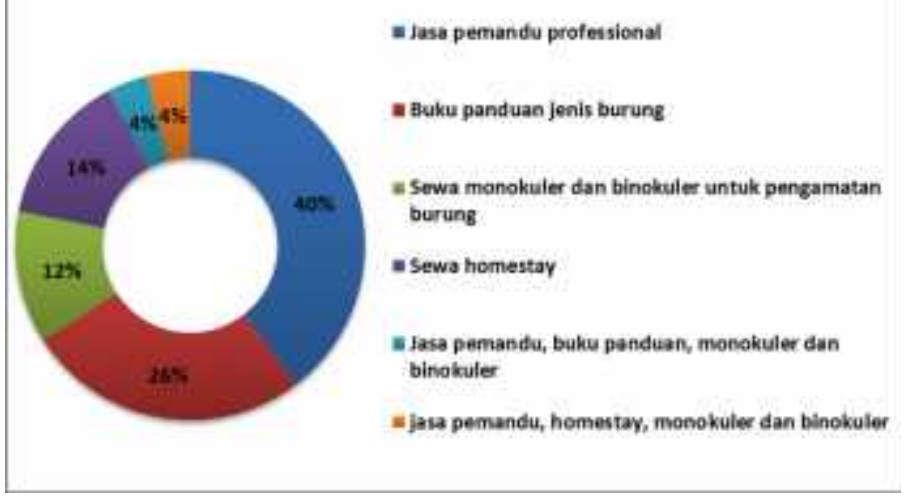

